\title{
Dr. Wonderful and the big bad asylum: Dissecting simplicty in The Snake Pit
}

\section{Adam Ruebsaat Trott}

Department of Philosophy, College of Arts, University of Guelph, Guelph, ON Canada. Faculty supervisor: Dr. Sofie Lachapelle. For correspondence, please email: ruebsaattrott@gmail.com.

\section{Abstract}

On the surface, Anatole Livak's The Snake Pit (1974) contains little more than a socially conservative overuse of pseudoFreudianism. The film has been rightfully criticized for its departure from the novel on which it was based, specifically in its more traditional approach to Virginia, its female protagonist. To simply dismiss The Snake Pit for these reasons, however, would not do justice to the film's importance within the history of cinema and psychiatry. This article will analyze the historical and cinematic factors that influenced Litvak's The Snake Pit, a film worthy of both praise for its social impact and blame for its failure to go far enough.

Keywords: Anatole Livak; cinema; history of psychoanalysis; Sigmund Freud; Hollywood

\section{Introduction}

From a 21 st century perspective, post-World War II America can often seem like a society rampant with anticommunism, misogyny and social conservatism. To a large extent, this reputation is not undeserved. The cinema of the time has been called into question on similar grounds. In particular, the overuse of pseudo-Freudianism in 1940s and 1950s Hollywood films has been heavily criticized for subjugating social issues to the psyche of mentally unstable individuals (Fishbein 1979; Semarne 1994). At first glance, Anatole Litvak's The Snake Pit appears to fit this mould perfectly. Released in 1949, the film tells the story of Virginia Cunningham (played by Olivia De Hallivand), a young and independent female writer who is admitted to Juniper Hill State Hospital following a nervous breakdown. Recently married, Virginia has begun to hear voices and has trouble recognizing her own husband. In the hospital, Virginia is left in the care of vindictive nurses and callous doctors and shows little sign of improvement. To her luck, the dashing Dr. Kik - a motivated psychiatrist employed by the hospital - takes an interest in her case. Dr. Kik treats Virginia with a mixture of electroconvulsive therapy (ECT), hypnotherapy and 'the talking cure.' Working with Dr. Kik, Virginia is finally cured of nervous condition. She is then able to accept her 'proper role' as a loving wife and leave the asylum.

As Fishbein (1979) notes, Virginia's story reads more like a psychology textbook than a real life account. Moreover, in Fishbein's view, Dr. Kik and his psychoanalytic method are the unquestioned heroes of The Snake Pit, relegating a serious societal issue (that state of American mental institutions) to a mere sidebar. It is certainly easy to view The Snake Pit as just another psychologically-themed film from an era that saw the production of dozens of such motion pictures. But, as this article will show, The Snake Pit deserves a closer look. While The Snake Pit unquestionably warrants much of the critique that has been aimed at it, an analysis of both the history of the film and the film itself prove that it is more than a simple glorification of patriarchal psychoanalysis.

\section{The Snake Pit, the History of Cinema, and Psychoanalysis}

\section{0-1930: A hesitant friendship}

In 1895, two developments brought much intrigue, misinformation and entertainment to the Western world. In the span of 12 months, Sigmund Freud published Project for a Scientific Psychology, the foundation for his psychoanalytic program, and the Lumière brothers invented the first motion picture system. Initially, the relationship between film and psychoanalysis was tenuous. Freud reputedly had distaste for the cinema (Schneider 1985). In 1925 , he was offered $\$ 100,000$ by producer Samuel Goldwyn to consult on a Hollywood film about famous love stories (e.g. Anthony and Cleopatra) (Sklarew 1999). Freud refused, claiming that he did not wish to sensationalize psychoanalysis. Nonetheless, psychoanalysis and film were closely linked from the outset. Freud's perceptual system bore an uncanny semblance to a camera lens and underdeveloped film was comparable to preconscious thought (Sklarew 1999). Cinema was even referred to as a 
"dream factory" by Russian writer Ilja Grigorjewitsch Ehrenburg (Gabbard and Gabbard 1995, p XXI).

While Freud rejected the allure of film, two of his colleagues jumped on the chance to be cinematic consultants. Karl Abraham and Hans Sachs were part of Freud's inner circle and were, as a result, some of Freud's closest disciples. In 1926, Austrian director G.W. Pabst released Geheimnisse einer Seele (Secrets of a Soul) - the first film to deal with psychoanalysis - to critical acclaim (Sklarew 1999). In Geheimnisse einer Seele, Pabst envisioned both an educational and dramatic depiction of Freud's new science. The protagonist, Martin, is a perfect case study: an impotent chemist who has a phobia of knives resulting from an impulse to slit his wife's throat. With the patient help of a competent psychoanalyst, Martin is cured after a series of dream interpretations. As a director, Pabst was known for his realism and he had a keen interest in psychoanalysis. Geheimnisse einer Seele offered a tempered view of the profession and boasted extensive dream sequences that are technically superior and more symbolically powerful than later blockbusters such as Hitchcock's Spellbound (Schneider 1985).

Despite the success of Geheimnisse einer Seele, Freud's skepticism continued as he expressed doubts that intricate concepts such as repression could be portrayed on the silver screen (Sklarew 1999). In Freud's opinion, cinema would merely simplify his complicated theories. Freud and Abraham exchanged a series of tense letters leading up to Abraham's death in 1925. When Sachs took over consulting on the film, he extolled its exciting potential. Following his work on Geheimnisse einer Seele, Sachs wrote a monograph on his experience, as well as the intersection between the film and psychoanalysis. In it, Sachs outlined the psychoanalytic interpretation of dreams and described the protagonist's observable symptoms (Sachs 1926; Chodorkoff and Baxter 1974). Interestingly, he stressed the limitations of a film adaptation of Freud's method. According to Sachs, it was impossible to explain the entirety of psychoanalysis in a single film. Instead, Geheimnisse einer Seele was merely a dramatized case study.

In the long run, Freud's fears proved to be justified. Over the next half century, psychiatrists were typecast into three essential roles: Dr. Dippy, the slow-witted 'specialist' used for comedic effect, Dr. Evil, the malevolent master of the mind, and Dr. Wonderful, the dashing doctor who saves the day (Schneider 1985).

\section{0-1950: The emergence of an American phenomenon}

For the sake of clarity, it is important to make note of the distinction between psychiatry and psychoanalysis. A practitioner of the former requires both a medical degree and a specialization in the field. As licensed physicians, psychiatrists are permitted to prescribe medication. An analyst, on the other hand, needs no formal medical training. Instead, s/he must have undergone therapy and studied under a registered psychoanalyst. Many psychiatrists are, however, also analysts, leading to the common conflation of the two. Hollywood has also been guilty of ignoring this difference. In the early days of cinema, psychiatrists were rarely portrayed as analysts, most likely because the discipline had not become prevalent in the new world. In the 1920s and 30s, analysts in the majority of Hollywood films were limited to acting as bumbling Dr. Dippys, reflecting the general attitude of America towards the discipline. For example, in The Boomerang (1925), Dr. Sumner is a general practitioner who is having trouble attracting patients. He becomes a 'psychoanalyst' and opens a sanitarium, which is exceedingly popular. Seeing the opportunity to make some good money, Virginia Zelva joins Dr. Sumner's outfit as a nurse and they fall in love. In Louis Gasnier's film, psychoanalysis is a cash-grab, not a legitimate profession.

In America, if psychoanalysis began to grow in popularity during World War II, it did not truly take off until the end of the war. A flood of returning American draftees with mental trauma was met by a swath of European psychoanalysts and psychiatrists who had escaped central Europe (Schneider 1985). As World War II reached its end, psychoanalysis was taken seriously in America. In Hollywood, analysts began to exercise more influence in films. As knowledge of Freud spread, psychiatrists began to use the talking cure with their patients, both in film and reality. In the cinema of the time, the analyst came to be seen as holding the key to unlocking the mind. In The Snake Pit, Dr. Kik is clearly part of this new generation of psychiatristanalysts. A portrait of Freud hangs over Dr. Kik as he applies the psychoanalytic method.

As part of the post-war cinema, The Snake Pit was made at a time when psycho-mysteries ${ }^{1}$ were particularly popular in Hollywood. These films expounded boundless optimism not only for the American nation, but also for the psychiatric profession. For a time, it even became common to see psychiatrists replacing detectives as the heroes of Hollywood cinema (Biskind 1995). Leaving Dr. Dippy behind, Hollywood cinema became permeated with optimistic images of the benevolent Dr. Wonderful. In the 1944 hit Lady in the Dark, Liza Elliott, a successful fashion editor, seeks the help of analyst Dr. Brooks after being troubled by the advances of three different men and the pressures of work. Dr. Brooks (played by Barry Sullivan) is empathetic and sophisticated, but most importantly, professional. His character is saturated with post-war pseudoFreudian mythology: Brooks is completely receptive, while offering little of own personality. Instead, therapy in Lady in the Dark is all about the patient. Both Liza and the audience are soothed by dramatized therapy sessions and lighthearted musical numbers. While Dr. Brooks may be a model analyst, the treatment itself is severely lacking. Freud's methods are simplified and the sessions are rendered harmless and almost jovial (Gabbard and Gabbard 1995).

At the same time as the boisterous psycho-mysteries, film noir came into its own as a genre. Noir films had a more pessimistic take on America. While they dealt mainly with the dark underbelly of crime, many films in the noir genre 
turned to the evils of the mind (Schneider 1985). In Nightmare Alley (1947), conman Stanton 'Stan' Carlisle teams up with Chicago psychologist Lilith Ritter. Using Ritter's confidential records, the two are able to make off with her patients' money. In the end, this malicious Dr. Evil and her sidekick are naturally found out, but not before they can wreak no little havoc. In both of the above cases, psychoanalysis became an added twist for more traditional movies. Instead of detectives and murderers, Hollywood could now offer psychiatrists and psycho-villains. In 1947, the psychiatrist Lawrence Kubie (1947, p 115) wrote:

To have a popular success on your hands, all you need is to make the psychiatrist into a... villain... or, alternatively, to remove the sting by turning the psychiatrist into a beautiful blonde who throws her arms around you between "treatments."

It is fairly self-evident that The Snake Pit is not a simple psycho-mystery. Is it thus a film noir? Again, this seems unlikely. Rather, it seems that it is part of a third trend that can trace its roots to the post-war period. As the war came to an end, many of the social conflicts that had been ignored during the fighting rose to the surface. As the name suggests, the so-called 'social problem' films attempted to tackle issues in society. It is within this context that The Snake Pit was conceived. The timing of the movie could not have been more perfect. In 1946, Life released a chilling exposé on Pennsylvania's Byberry and Ohio's Cleveland State hospitals, entitled 'Bedlam 1946: Most U.S. Mental Hospitals are a Shame and a Disgrace.' Mental hospitals across the country were described as "little more than concentration camps" (Maisel 1946, p 102). Spotting this social crisis, Litvak jumped on the chance to direct a film on the subject.

While the genre did not truly take off until the 1960s and 70s, social problem films began more modestly in the late 1940s. Crossfire (1947), a who-done-it detective story, took on anti-Semitism, albeit in a simplistic manner. Joseph Samuels, a young Jewish man, is found murdered and police captain Finlay is called in to solve the case. As he investigates a group of recently discharged soldiers, Finlay discovers the sinister motive behind the crime: army sergeant Monty Montgomery, a rabid anti-Semite, murdered Joseph in a drunken stupor after learning that he was a Jew (Crowther 1947). Although Finlay lectures the audience on the dangers of anti-Semitism, Montgomery's capture seems to put an end to the problem. This kind of 'happy ending' was to some extent expected in post-war cinema; however, it rests particularly uneasily in the social problem genre. Early social problem films were especially interesting, because, while they shared the responsibility of 1960s and 70s cinema, they were not immune to the naiveties of 1940s and 50s Hollywood. This tension would come to play a key role in The Snake Pit.

\section{Biography, Cinematography, and Inconsistency}

\section{Anatole Litvak and The Snake Pit}

Anatole Litvak, an ethnic Jew born in Kiev, lived in Germany before immigrating to the United States (Brook 2009). Litvak began his career directing musicals and comedies in France, England and Germany in the late 1920s and early 1930s. By the late 1930s, Litvak obtained a contract with Warner Brothers and left for America (Brook 2009). Motivated by political and social issues, Litvak began directing more serious films. His 1939 film Confessions of a Nazi Spy, was one of just three anti-Nazi films created before American involvement in the war. In the film, FBI agent Ed Renard (played by Edward G. Robinson) investigates a Nazi spy ring designed to gain support among German Americans for the Nazi cause. While Renard uncovers the ringleader, a number of the spies are whisked back to Germany. Litvak's social criticism in Confessions of a Nazi Spy was not far off the mark: in 1941, a ring of 33 Nazi spies was tried and convicted by the FBI (Fried 1999). Confessions of a Nazi Spy marked Litvak's turn to directing films motivated by social and political issues.

Litvak's social concerns are also reflected in The Snake Pit. However, here the enemy is no longer foreign. Instead, the villain of The Snake Pit is the psychiatric institution itself. Litvak took inspiration from Mary Ward's 1946 novel, also entitled The Snake Pit. Ward's work is the fictional firstperson account of Virginia Cunningham, a leftist female writer who is brought to the brink of sanity because of the financial struggle that she and her husband are facing. Ward based The Snake Pit loosely on her own eight month stay in a public mental hospital (Fishbein 1979). Although it was meant to be fictional, Ward's account was not far from the truth. As 'Bedlam 1946' attested, Ward's account actually understated the dire conditions in the average American mental hospital. After reading Ward's novel, Litvak bought the rights immediately (Fishbein 1979). He intended his film adaptation to be a revealing account of the state of American mental institutions. While Confessions of a Nazi Spy had had moderate success in the box office, The Snake Pit became a hit. The film boasted long shots depicting the everyday struggle of patients in the ineffective mental hospital system. The ineptitude of the hospital staff is highlighted throughout, with jealous nurses and unsympathetic doctors. Moreover, The Snake Pit actually provided a basic overview of methods current to psychiatry and psychoanalysis (e.g. ECT and hypnotherapy) in a fairly undramatic manner. The American press were delighted that a director had taken a more serious look at those suffering in American mental hospitals (Fishbein 1979). Time, The New Republic and Rotarian all extolled the film's nuanced social responsibility. The New York Herald Tribune's Howard Barnes applauded the film's verisimilitude and Litvak's audacity in tackling a topic left almost untouched by Hollywood cinema (Fishbein 1979). 


\section{Filming}

From the above analysis, it seems likely that The Snake Pit is a social problem film; however, this is not to say that it is beyond critique. That Litvak took pains to make his film both believable and realistic is undeniable. He envisioned the first authentic film examination of mental illness in an institution. In fact, over a three-month period before shooting, Litvak travelled to a wide variety of mental hospitals with his entire cast (Clooney 2002). While on the road, the group also attended lectures from prominent American psychiatrists. Litvak's female lead needed no encouragement in this endeavor: Olivia De Hallivand researched with a surprising fervor, carefully examining popular treatments including ECT and hydrotherapy (Clooney 2002).

On the other hand, the film's departure from the book it was based upon reveals a neutralization of much of the latter's feminist narrative. While Ward's The Snake Pit was clearly written from a female, first-person perspective, Litvak chose not to shoot the film in this way. Instead, much of it was filmed from a 'neutral' standpoint. This turn from the subjective to the objective perspective shifts the tone of the entire story. It isolates the audience from the protagonist and relies on the doctor to be the truthful storyteller (Fishbein 1979). The 'expert' is no longer Virginia the patient, but Dr. Kik, the psychiatrist. In Ward's novel, Virginia is a mother and an accomplished writer with two published books (Fishbein 1979). However, In Litvak's adaptation, Virginia is unpublished and a childless newlywed. Virginia herself appears childish and, after only a short time being married, falls prey to mental breakdown.

How are these alterations to be rectified with Litvak's apparent dedication to the authenticity of his social problem film? Perhaps Litvak wanted to focus on the condition of mental hospitals and Mary Ward's story was simply a vehicle to do so. This solution, while possible, would be fairly unsatisfactory. It is more likely that Litvak was cognizant of studio pressures in the production of his film. The Snake Pit was a hard sell: Litvak was turned down by every studio he had previously worked with (Clooney 2002). The reason behind their decision is clear: The Snake Pit was neither a thriller nor 'entertainment' (Clooney 2002). If Litvak had included the book's feminist undertones, it is unlikely that any studio would have taken him. The film's true importance for Litvak was the problems it raised with medical institutions. From an 'objective' standpoint, he would have gained more credibility with his audience. Litvak may have felt forced to alter Virginia in order to garner the necessary publicity for his film. For example, in the wildly popular Lady in the Dark, Liza Elliott's analyst tells her that she has rejected her femininity and dominates men. At the film's end, Liza falls in love with co-worker Charley Johnson and even offers to give up her position at the fashion magazine. Lady in the Dark was just one of a slew of such films. Thus, by fashioning his female lead in a similar manner, Litvak would have had better chances at reaching a wider audience.

\section{The conspicuous cure}

The above tension is related to a paradox inherent in Litvak's plot: The Snake Pit critiques the psychiatric system while lauding Dr. Kik, himself a psychiatrist. Litvak's criticism of the institution is clear. The state hospital in which Virginia finds herself is filled with impatient nurses and uncompromising doctors. Instead of improving, her condition deteriorates. That is, until the arrival of Dr. Kik. The handsome psychiatrist distinctly embodies the detectivelike Dr. Wonderful: he sits in his office smoking cigarettes and cracking the case of Virginia Cunningham. In the end, it seems that the talking cure reigns supreme. Through lengthy sessions, Virginia's quasi-oedipal complex is revealed. As a young girl, Virginia was attached to her father, but as he began to take her mother's side in disciplining Virginia, she became jealous. As a result, Virginia tore up a male doll, representing her father. Soon after, Virginia's father developed a terminal illness and died. All of Virginia's later relationships with men were unhealthy, because she felt conflicted between her attraction to them and her love for her deceased father. Upon discovering this, Virginia can finally return to her waiting husband as a mentally stable member of society.

However, upon deeper inspection, psychoanalysis alone does not cure Virginia. Towards the end of the film, Virginia is transferred to the 'snake pit,' the ward for the deeply disturbed. The 'jolt' of this new unsettling environment causes Virginia, with the help of Dr. Kik, to see the roots of her disorder. Virginia's epiphany does occur in the presence of the psychiatrist; however, without the stimulus of her surroundings, Virginia would not have escaped the grips of mental illness. Thus psychoanalysis, while prominent, is not all-powerful in The Snake Pit. Instead, environmental stimulus is the ultimate catalyst. The snake pit that shocked Virginia out of her illness was also designed to ignite the outrage of the audience. With sinister lighting and deranged inmates, Litvak made this ward look like a literal pit of snakes. This scene stood as a centerpiece in Litvak's dramatic examination of the American mental hospital. It is also worth noting that, while Dr. Kik makes extensive use of psychoanalysis, his inept colleagues seem to be more traditional psychiatrists. It could be argued that The Snake Pit was Litvak's way of promoting the use of psychoanalysis, though this would likely be reading too much into the film. Instead, it seems that Litvak saw the talking cure as a successful treatment at the time. It was simply part of a broader program of sincerely attending to the needs of patients - at least in Litvak's eyes.

While the film is a far cry from Ward's scathing critique of psychiatry, it does not offer unconditional support of the profession. The Snake Pit criticizes state hospitals but does not promote a full-scale rejection of psychiatry. There was a genuine possibility that, if Litvak's film was too radical, its audience would have abandoned psychiatry 
altogether in a similar fashion to the audience of One Flew over the Cuckoo's Nest. Milos Forman's adaptation of Ken Kesey's novel inspired an entire generation of antipsychiatry and the profession has had difficulty recovering from the aftermath of the film. Dr. Eric Cunningham, a British psychiatrist, was so concerned with the impact of The Snake Pit on a British audience, that he insisted that a precautionary preface be added to the movie to show that it did not depict the British psychiatric profession (Cunningham Dax 1949). Crowther from The New York Times wrote, “"The Snake Pit,' while frankly quite disturbing, and not recommended for the weak, is a mature emotional drama on a rare and pregnant theme" (Crowther 1948). It is possible that Dr. Kik was Litvak's attempt at sobering The Snake Pit or perhaps it was simply another attempt to make the movie more entertaining to gain the support of film studios. Litvak should rightly be criticized for The Snake Pit's inherent paradoxes; however, the film should not be stripped of all merit. After all, it did in fact launch a public outcry against the state of mental institutions.

\section{Conclusion}

Litvak's The Snake Pit is through and through an early social problem film. Inspired by the desire to do good, it was stymied by the cinematic climate of its time. Although the film creates as many problems as it solves, it is clear that The Snake Pit is anything but simplistic. First, it intentionally raises a problem - the condition of mental hospitals plaguing post-war America in a complicated and profound way. The film's straightforward end, however, is not adequate with respect to the intricacy of the social issue it tackles. Second, it is strange that a socially conscious director such as Litvak weakened the role of his female protagonist from the originally emancipatory standpoint of Ward's novel. The Snake Pit is rife with ambiguity, inconsistency and outright paradox. Despite its shortcomings, Litvak's film achieved what it was intended to do. While it bafflingly ignores the feminist themes of the book while simultaneously praising and blaming psychiatry, The Snake Pit stands out in post-war cinema because of its immense social impact. By reaching a wide audience, The Snake Pit was able to expose the dehumanizing effects of mental hospitals to the general public.

\section{Endnote}

1. It is important to note that these films were not necessarily crime-related. Instead, the 'mystery' was the patient's case-study.

\section{Acknowledgements}

This article was a result of research done as part of seminar on the history of madness and psychiatry. I would like to thank Dr. Sofie Lachapelle for guiding me throughout this process and Dr. Jeff Mitscherling for showing me that thinking about art is both a vital and complicated task.

\section{References}

Atkinson R. 2005. Revisiting a classic: The Snake Pit. Clinical Psychiatry News. 33(8): 21.

Biskind P. 1995. Seeing is believing: how Hollywood taught us to stop worrying and love the fifties. New York: Pantheon. 371 p.

Brook V. 2009. Pathological noir, populist noir, and an act of violence. In: Brook V, editor. Driven to darkness: Jewish émigré directors and the rise of film noir. New Brunswick (NJ): Rutgers University Press. p. 185-212.

Chodorkoff B, Baxter S. 1974. "Secrets of a Soul": an early psychoanalytic film venture. American Imago. 31(4): 319-334.

Clooney N. 2002. The movies that changed us: reflections on a screen. New York: Atria Books. 256 p.

Cunningham Dax DE. 1949. The Snake Pit. The Lancet. 253(6557): 754-755.

Crowther B. 1947 July 23. 'Crossfire' study on tolerance, starring Robert Young and Robert Ryan, opens at Rivoli - Antry and Rogers at Rialto [Internet]. New York (NY): The New York Times; [cited 2014 Feb 14]. Available from: http://www.nytimes.com/movie/review?res=9A02EED8 1E3EE13BBC4B51DFB166838C659EDE

Crowther B. 1948 Nov 5. 'Snake Pit,' study of mental ills based on Mary Jane Ward's novel, opens at Rivoli [Internet]. New York (NY): The New York Times; [cited $2014 \mathrm{Feb}$ 14]. Available from: http://www.nytimes.com/movie/review?res=9901E5DF1 43CE733A25756C0A9679D946993D6CF

Fishbein L. 1979. The Snake Pit (1948): the sexist nature of sanity. American Quarterly. 41: 641-665.

Fried J. 1999 Oct 18. Thrillers of cold war in a hall of justice [Internet]. New York (NY): The New York Times; [cited $2014 \mathrm{Feb}$ 14]. Available from: http://www.nytimes.com/1999/10/18/nyregion/thrillersof-cold-war-in-a-hall-of-justice.html

Gabbard K, Gabbard G. 1995. Psychiatry and the cinema. Chicago (IL): The University of Chicago Press. 304 p.

Kubie L. 1947. Psychiatry and the films. Hollywood Quarterly. 2: 113-117.

Maisel A. 1946 May 6. Bedlam 1946: most U.S. mental hospitals are a shame and a disgrace [Internet]. New York (NY): Life Magazine; [cited 2014 Feb 14]. Available from: http://www.pbs.org/wgbh/americanexperience/features/p rimary-resources/lobotomist-bedlam-1946/ 
Sachs H. 1926. Secrets of a Soul: a psychoanalytic film. Berlin (DE): Lichtbild-Buhne.

Schneider I. 1985. The psychiatrist in the movies: the first fifty years. In: Reppen J, Charney M, editors. The psychoanalytic study of literature. Hillsdale (NJ): The Analytic Press. p 53-67.
Semarne V. 1994. The Snake Pit: a woman's serpantine journey towards (w)holeness. Literature/Film Quarterly. 22(3): 144-50.

Sklarew B. 1999. Freud and film: encounters in the Weltgeist. Journal of the American Psychiatric Association. 47: 1238-47. 